Mid-American Review of Sociology

Myerhoff, Barbara G.

1978 "A Symbol Perfected in Death: Continuity and Ritual in the Life and Death of an Elderly Jew," Ch. 5, pp. 163-202 in Barbara G. Myerhoff and Andrei Simic (eds.) Life's CareerAging, Beverly Hills and London: Sage Publications.

Rosenthal, Carolyn J., Victor W. Marshall, A.S. Macpherson and Susan

B. French

1980 Nurses, Patients and Families. New York: Springer and London: Croom Helm.

Ross, Jennie-Keith

1977 Old People, New Lives. Chicago: University of Chicago Press.

Schatzman, Leonard and Strauss, Anselm L.

1973 Field Research. Englewood Cliffs: New Jersey: Prentice-Hall.

Seiber, Sam D.

1973 "The Integration of Fieldwork and Survey Methods," American Journal of Sociology 78, No. 6 (May):1335-1359.

Shaffir, William, Victor W. Marshall and Jack Haas

1980 "Competing Commitments: Unanticipated Problems of Field Research," Qualitative Sociology 2 (No. 3):56-71.

Stephens, Joyce

1976 Loners, Losers, and Lovers. Seattle and London: University of Washington Press.

Tindale, Joseph A.

1980 "Identity Maintenance Processes of Old Poor Men," Ch. 9, pp. 88-94, in Victor W. Marshall (ed.), Aging In Canada: Social Perspectives. Toronto: Fitzhenry and Whiteside.

Webb, Eugene J., Campbell, Donald T., Richard D., and Sechrest, L.

1966 Unobtrusive Measures: Nonreactive Research in the Social Sciences. Chicago: Rand McNally.

\section{DEATH AND MENTALLY RETARDED PERSONS}

\author{
Daryl Evans \\ University of Kansas
}

Mid-American Review of Sociology, 1981, Vol. VI, No. 2:45-60

Special images associated with the concept of death are applied to people who are mentally retarded. The images reflect, and are reflected in, social attitudes which often lead to alienating experiences for retarded persons. These experiences and the special images and social attitudes which are their antecedents are discussed. Brief attention is given to the reversal of the normal loss-grief sequence associated with death as it relates to mentally handicapped persons. The material for this exploratory study was gathered through: 1) participant observation, 2) interview and guided conversation, and 3) literature review.

\section{MENTAL IMPAIRMENT: WHO CARES?}

Mentally retarded persons constitute a sizable, but largely unknown, minority in our society. While there is controversy about incidence figures, it is generally accepted by professionals in the field of mental retardation that approximately three percent of the total population of the United States is mentally retarded (Gearheart and Litton, 1975:1). Despite the demographic magnitude of this figure, the findings of one investigation indicated that a very low percentage (as little as one percent) of the general population possess accurate or relevant information regarding mental retardation (Gottwald, 1970).

Such a finding is noteworthy because the special problems and needs of mentally handicapped persons are becoming more conspicuous in America as its citizens begin to experience the consequences of the so-called normalization/deinstitutionalization movement. The process of normalizing retarded people is said to utilize, "means which are as culturally normative as possible in order to establish and/or maintain behaviors which 
are as culturally normative as possible" (Wolfensberger, 1972 28). This process has culminated in legal mandates such as Public Law 94-142 (The Education for All Handicapped Children Act of 1975) which are forcing changes in the traditional patterns of interaction between non-handicapped and mentally retarded people. For example, retarded students have increasingly come to share schools with non-handicapped peers. Mentally retarded persons are also moving into neighborhoods once off limits to them, and finding competitive employment in the American labor market. On the basis of proliferating litigations surrounding such changes, it is apparent that the integration of mentally handicapped people into the social mainstream has, in many settings, contributed to a climate of social tension if not conflict.

One element of that contentious atmosphere can be traced to special associations between mental retardation and the concept of death. We shall see that there is a historical legacy which views mental retardation as the functional equivalent of death-a view which sometimes results in retarded people being treated as though they were dead, or ought to be.

Literal Death-Tardocide. The negative attitudes toward the vitality of mentally retarded life as viable life are manifold in history. A few examples will suffice to bring this history into sharper focus. The Spartan lawgiver Lycurgus (c. 900 B.C.) prescribed death for "idiots" in an attempt to keep Spartan society free of defectives (Gearheart and Litton, 1975:1).

The Protestant Reformers carried on the long tradition of tardocide, but with a new twist. They relegated mental retardation to a form of Satanic unreason. Because retarded people were thought to be "possessed," many were tortured and/or killed to exorcise demons (Dunn, 1961:14; Frampton and Rowell, 1938:167; Love, 1973:40). In fact, since retarded people were thought to be servants of Satan, many clerics argued that they should be treated more harshly than criminals such as murderers (Kanner, 1964:6). A quote from Martin Luther $(1652: 387)$ recapitulates the attitudes of many of his fellow reformers. He writes:
Eight years ago, there was one at Dessau whom I, Martin Luther, saw and grappled with. He was twelve years old, had the use of his eyes and all his senses, so that one might think that he was a normal child. But he did nothing but gorge himself as much as four peasants or threshers. He ate, defecated, and drolled, and if anyone tackled him, he screamed. If things didn't go well, he wept. So I said to the Prince of Anhalt: 'If I were the Prince, I should take this child to the Moldau River which flows near Dessau and drown him.' But the Prince refused to follow my advice. Thereupon I said: 'Well, then the Christians shall order the Lord's Prayer to be said in church and pray that the dear Lord take the Devil away.'

The status of mentally retarded people as an expendable minority reached its denouement in Hitler's Germany. The "ultimate solution" resulted in the deaths of as many as 100,000 mentally retarded people (Wolfensberger, 1981:3).

The expendability of retarded people is apparent even today. The methods may not be as direct as those employed in Sparta or Auschwitz, but the results are still the same. Duff and Campbell (1973:892) found widespread de facto euthanasia of defective children in a study of a special care nursery. Robertson (1975:214) reports that withholding treatment from handicapped babies " ... is rapidly gaining status as 'good medical practice." "

Parents wield a great deal of power in the decision to euthanize a defective child. For example, in the widely-publicized "Johns Hopkins Case," a baby born with Down's Syndrome and a duodinal obstruction was allowed to die at the request of his parents (Hardman and Drew, 1978:394). The obstruction was easily correctable by simple surgery, but the parents withheld their permission for the operation and the baby died of starvation fifteen days later. Children with Down's Syndrome typically get along quite well in life with proper care and training.

A related case was that of "Baby Boy Houle." After parents refused to give their permission for a life-saving operation for the child, a judge ruled: "At the moment of live birth there does 
exist a human being entitled to the fullest protection of the law" (McCormick, 1974:172). Yet the law may be empty legal rhetoric. Robertson $(1975: 247)$ indicates that physicians are rarely prosecuted for withholding ordinary medical care from a defective infant even if it results in the death of the child. Robertson also holds parents to be immune from this liability.

The degree to which an euthanistic ethos toward retarded people exists in our society has not been subjected to a rigorous investigation. Moreover, it is difficult to determine the extent to which any given retarded person is cognizant of his/her expendability where such an ethos exists. This would require very delicate research. A few retarded people do volunteer feelings on this matter, though. One woman said to me: "Some people think we're useless, you know, that the world could get along without us. Well, we're not."

Symbolic Death-Separation. Despite the excesses of the Reformation, the spirit of the Enlightenment diminished somewhat the fervor for killing retarded people. That notwithstanding, during the Seventeenth Century a precedent was set for the symbolic equivalent of killing them. To wit, they were separated from the rest of society. During the Seventeenth Century, retarded people began to be confined in total institutions euphemistically referred to as "asylums," "schools," or "hospitals." Total separation was an "out of sight, out of mind" solution to the "problem" of defectives which was given added impetus by the rise of Social Darwinism and the eugenics movement. We see, however, that the effects of total confinement often led to more than figurative deaths of retarded people.

For example, in the early Twentieth Century, many mentally retarded persons were dying in houses of confinement of diseases not related to preexisting physical or mental conditions. White and Wolfensberger (1969:8) cite some sobering statistics:

Less than a third of those committed to the care of Elwyn School [a large institution for retarded persons generally considered to be one of the better ones of the time] lived to the age of twenty. Eight out of 625 made it to forty. The most common cause of death was tuberculosis, although a smaller percent died of consumption at Elwyn than statistics quoted for institutions as a whole across the country.

As times have changed, so have institutions. Most have been the objects of reform efforts, and the vast majority of mentally retarded people have been deinstitutionalized. It is estimated that about three percent of the retarded population still live in institutions (National Association for Retarded Citizens, 1974: 20). Nonetheless, deinstitutionalization is not synonymous with social integration. In some instances, there is pro forma integration which does not lessen the feelings of separateness and isolation that characterized institutional life. For example, it is common for there to be public outcries when residential facilities for retarded persons are proposed in "normal" neighborhoods. Zoning ordinances, codes, and costs frequently push such facilities into commercial or industrial areas (The President's Committee on Mental Retardation, 1973:23). Here, although the handicapped person is out of the confines of the total institution, it is often difficult for him to get to where the "normal" people, live, work, shop, and play.

Even if the retarded person is content to live in his "own world," there are certain factors which militate against the development of lasting relationships with "significant others." These factors often force the handicapped person into perpetual cycles of loss and grief. One such factor is the high mortality rate for retarded people (Richard, 1976:168; Farber, 1968:92). It is fairly common for retarded friends to be separated from each other because of the premature death of one or the other.

A second factor which contributes to the transitory interpersonal relationships of some retarded people is the rapid turnover rate of help in residential facilities. Total institutions are notorious for this phenomenon. For example, it is reported that a retarded resident might see and adjust to as many as 20 new caretakers over a six-month period (Zaharia and Baumeister, 1978:581). Staff and volunteers in community-based residential facilities come and go with great frequency as well. Mentally handicapped people frequently develop important attachments to these transitory workers. I observed that many people who 
work in residential settings with retarded people fail to recognize how much the latter come to depend upon them, and that the disappearance of one of these "significant others" can easily precipitate a grief response.

A third factor which contributes to instability in the interpersonal relationships of retarded people, and thus accentuates their separateness, is what I call the "residential shuffle." It is not uncommon for a retarded person to be moved between institutions or community-based residences, or back and forth between both, many times during a lifetime. Aside from forcing the resident to adjust continuously to new physical and interpersonal environments, this creates anxiety about the future and separates him from significant others. The comments of one man intimate the phenomenon:

Sometime in the 1920's my folks moved to Colorado. Then in my sixth year they put me in a home and I grew up there. I guess my folks had me put there because they was too poor to take care of me. Those kids wouldn't leave me alone there; they were mean to me and I ran off from there about nine times-from that institution-and they filed charges against me and sent me to [another institution]. Some authorities from juvenile court I think-there's four men with yellow hair-they asked me a bunch of questions and then they said, 'Send him to [names another institution].' I was there seventeen years. It was better, but you couldn't get out ... unless an attendant was with ya; they're the ones that carry the keys. Well, after seventeen years, they sent me to [names another institution]. I was there thirteen years and then they shipped me to [names a community-based residential facility].

Compared to some of his peers, this man has led a rather sedentary existence. Some retarded people are moved constantly, and those who have experienced a frenetic dose of the residential shuffle become conditioned to expect that interpersonal relationships will not be abiding and become wary about forming them in the first place. These people become isolates within their "own world."
Even in the major channels of the social mainstream, retarded persons often feel separate. One woman described her experiences in "regular schools" as follows:

I didn't have many friends in special education. I was more or less alone, like an alone kind of kid because the rest of the kids would always make fun like in junior high. All they did was make fun. They didn't seem to wanna understand. It made me feel really torn up inside.

\section{LIVING FOSSILS}

As clergymen and eugenicists lost their preeminence as definers of whether and how retarded people should live, physicians ascended to the top of the "hierarchy of credibility" as definers of the social roles retarded people were to play. In the imagery of the so-called "medical model," retarded persons are seen as sick people who do not play the "sick role" very well. For one thing they are not curable. This negates the whole thrust of medical education. Physicians frustrated by the conundrum presented by a retarded patient may succumb to one of the aforementioned methods of dealing with retarded people in a kind of medical regression. First, if the patient is sick enough, the doctor may facilitate his death either actively or passively. Second, the doctor may get the patient out of his sphere of professional influence by suggesting immediate institutionalization. For example, Kelly and Menolascino (1975:11) found that eighty percent of the physicians they surveyed in 1975 automatically recommended institutionalization of severely and profoundly retarded children. Third, the physician may establish a totally static relationship with the patient. Since the patient is incurable, he comes to be looked upon as a fixed physical, mental, and psychological entity, which, in effect, implies that he is not alive at all.

Where this attitude becomes dominant, certain tendencies retarded people have toward personality rigidity are exacerbated. We know that retarded persons have more anxiety about 
failure than do normal people (Bialer, 1970:79; Snyder, 1966: 40). We also know that this anxiety breeds passivity (Zigler, 1970:178). Bialer (1970:83) tells us:

... there seems to have been a conspiracy on the part of society in general to render all situations 'old' by offering the retarded child minimal exposure to experiences that were not already within his behavioral repertoire or to structure novel situations so rigidly that pathways to goals were very sharply delineated and mobility was possible only in specific directions.

Combine this encapsulation of a retarded person in the " $\mathrm{fa}$ miliar" (the logical extension of the application of a static model) with an inherent tendency toward passivity and the result can be a morbid fear of novelty and a fixed personality style. Watts (1951:41) describes it this way:

Life and death are not two opposed forces; they are simply two ways of looking at the same force, for the movement of changes is as much the builder as the destroyer. The human body lives because it is a complex of motions of circulation, respiration, and digestion. To resist change, to try to cling to life, is therefore like holding your breath; if you persist you kill yourself.

The same might be said of the mind and identity of a retarded person who becomes a living fossil in a world of static imagery.

De facto euthanasia, an abiding thrust toward separation of retarded people from mainstream society, and the static view of them inherent in the medical model are three typifications of the social equation of retardation with death or death-like imagery. The strength of the argument that such an equation exists may dim as the premises become more metaphorical, but there is hard evidence as well. For example, in a survey in which respondents were asked to rate disabilities according to their levels of acceptability, Tringo (1970) found that mental retardation ranked well behind conditions that one might think would have the more pathological connotationsthings such as heart disease, stroke, tuberculosis, and cancer, to name only a few.

\section{WHEN BIRTH IS MOURNED}

Pathological social images of mental retardation can act as potent constituents in the attitudes of parents of retarded children toward their youngsters. It is not uncommon for the birth of a retarded child to evoke a grieving response in parents. As one mother put it: "It's like someone came and told you your child was dead" (Waskowitz, 1959:320). Several researchers hold that during pregnancy, parents create a vision of the "ideal child" they are going to have. The birth of the defective child is seen as the death of the ideal child (Solnit and Stark, 1961: 524; Olshansky, 1966:21). A pediatrician told me: "The symbolic death involved in having a retarded child may be worse than actually losing a real child. They look at the retarded kid every morning and he dies all over again."

Parents of retarded youngsters occasionally mourn more than the death of the ideal child. A few mourn the dislocation of the whole family unit-the death of the family, so to speak. One mother, in referring to the birth of her retarded child, said: "I had the feeling that everything in the world had ended.... It would be better if the whole family could be wiped out" (Farber, 1960:5). Pearl S. Buck (1950:134) made the following statement in reference to her retarded child:

All the brightness in life is gone, all the pride in parenthoodthere is more than pride gone: there is an actual sense of one's life being cut off in the child. The stream of generations is stopped.

In fact, the stream of generations may literally be cut off. The mother of a mentally handicapped child told me: "After we had our boy, the thought of another child terrified and sickened me. I could not have sex with my husband for several years."

The self-disparagement involved in giving birth to a mentally handicapped child translates into self-destructive impulses on the part of certain parents. A mother said: 
I always thought of myself as a failure until I got pregnant, and then I felt I was just as good as anyone else. But after the child came, I realized that I had failed everything and I didn't want to live anymore (Michaels and Schucman, 1962:570).

The suicide rate among parents of retarded children is said to be twice that of the national average (Love, 1973:162).

The pathological imagery of parents regarding mentally retarded children can manifest itself in other ways. Witness the following account:

At one time it was the practice to have babies who were diagnosed as retarded at birth immediately institutionalized. The parents then told their friends and relatives that the child was either stillborn or had died shortly after birth and placed an obituary in the local newspaper. In this way parents acted out symbolically the death of the child (Hart, 1970:57).

Institutionalizing a retarded child at birth is one way to deny its existence. There are other facets to the denial ritual For instance, parents may alter the normal process of social intercourse to avoid being identified with the retarded child. Kurtz (1977:11) describes one father who "traced an outline of his retarded child's foot on a cardboard, taking this to the store to buy a pair of shoes so the child would not be seen in public."

Some parents dream of killing their retarded children. One mother describes her dream as follows:

I dreamed that my child was lying in my arms and I was loving him, just as I do when I am awake. Then a hand with a pistol came through the window, and my poor little baby was shot through the head. I tried and tried to save him, but I could not keep him from dying (Michaels and Schucman, 1962:571).

The repressed impulse to kill the retarded child comes out in daydreams as well. Josh Greenfeld, in one of the popular accounts of his retarded son, Noah (1978:154), describes his fantasies:
A horrible weekend. I thought continually that soon I will have to kill Noah. The monster that has long been lurking in him increasingly shows its face. And just as the day may come when I can no longer bear to take care of him, I could not bear to see him mistreated-or maltreated-in a state hospital.... Killing him would be a kindness. His brain has stopped working; and he has not been functioning anyway. I dread it but I see myself killing my son not as a myth but as fact... .

There is a man from Santa Barbara who killed his brain-damaged son a few years ago. He put a gun to the boy's head and squeezed the trigger, then called the police. He's in prison. But he'll get out eventually.

\section{MIRROR, MIRROR ...}

Social images that equate mental retardation and death also act as powerful constituents in the consciousness of some retarded people. If, for example, parental grieving for the ideal child is protracted, the retarded child may sense his role in the loss. Some of these children doubtless have an ambiguous feeling that they ought to be a surrogate for the child the parents really wanted. During the period of my observations, it was not uncommon to see parents frustrate and confuse a retarded youngster by having expectations for him which only a normal child could meet. When expectations are too high, the retarded child is overstimulated. When the child fails to meet the expectations, the parents may then despair and understimulate the child, overlooking the possibility that he might have any developmental potential-adopting a static approach which parallels that discussed earlier. The process of overstimulation, then understimulation can be pendulous and go on for many years; but the message is clear: "You're not what we wanted. Why do you have to be alive?"

Some retarded children recognize themselves to be the focus of family disorganization or the total disintegration of the family unit. The divorce rate of parents of mentally retarded children is said to be three times that of parents who do not 
have retarded youngsters (Love, 1973:162). Some retarded youngsters may come to see themselves as pivotal factors in the death of the family.

Societal images of the retarded life can translate into death wishes or auto-aggression by retarded people. For example, it is reported that suicidal fantasies are common among retarded persons (Berman, 1967:20). My own stereotypical view of the "blissful ignorance" of retarded children was eradicated the first week I was in the field, when an adolescent tried to kill herself. Some of the mentally handicapped people I came to know talked about killing themselves almost daily. A few tried. None succeeded.

Aggressive impulses are not always self-directed. Just as the parent may fantasize about killing a retarded child, so may the youngster think about the death of the parent. One of the strangest moments $I$ had in the field centered on this issue. During the course of a lesson, a special education teacher in a school for moderately retarded students (I.Q. 40-54) said to a class of approximately twenty 18-21 year-old pupils: "Someday your parents will die." The classroom erupted in applause. For some of the students, this was purely a collective response. On the basis of my conversations with others, some clearly relished the idea. A lifetime of enduring the special complexities involved in the parent-child relationship breeds a lot of resentment in some handicapped children.

Just as some parents symbolically disavow the life of the retarded child by denying the filial relationship, so may the retarded child disavow his own identity. It is a common phenomenon among retarded people to attempt to "pass" as normal (Edgerton, $1967: 144-171)$. When a mentally handicapped person engages in what Goffman (1963:122) called "phantom normalcy," they not only deny life as it is, but the false identity that is substituted is always in jeopardy of being discovered and killed.

\section{REPRISE}

Being mentally retarded in a world which places a high premium on intelligence puts a heavy burden on handicapped persons. The "brightest" must grapple with the morbid implications of their handicap on an ideational level. All retarded people face the consequences of the following factors on an experiential level:

1. Historically, retarded people have been seen to be a surplus population. If not deemed an expendable class as a matter of course, they have been viewed as firstline expendables during eugenic purges and hard times. Today, some retarded people are still killed or allowed to die.

2. Where separation from the social mainstream by death has not been approved, separation by confinement has been substituted. There are many ways to confine and separate people, even under the pretense of integrating and normalizing them. Spectral barriers and the selffulfilling prophecies inherent in static definitions kill vital identities just as surely as death camps kill bodies.

3. In the family setting, there are many associations between the birth of a mentally retarded child, or the identification of the handicap, and death-between mental retardation and grief.

\section{LOSS-GRIEF DISJUNCTION}

It is with the third of the aforementioned factors that retarded persons face one of the most paradoxical problems associated with their handicap. Many of them only experience the grief the handicapping condition evokes with no corresponding sense of the precipitating loss. It is a Catch-22 because the source of their stigma is intellectual deficiency; but in order to understand the roll of that deficiency in the grieving process, they must use cognitive abilities, the lack of which are the source of the stigma. Thus the experience of grief (as manifested in all the morbid images and experiences associated with the stigma of retardation) preceeds a grasp of the loss (that 
which must, but cannot be, understood). Those individuals who have no causal antecedents to explain the grieving process they become the focus of, have no reasonable course of adaptation. Defenses are useless when one does not know what he is defending against. Thus for some, bereavement becomes a lifestyle.

That is not to imply that retarded individuals who understand the connection between the loss and its attendant grief are much better off. While these persons have the advantage of being able to adapt to the loss through such devices as "passing," recognition of the content of the loss brings them face to face with the reality that their adaptation must eventually fail. The reason is simple to understand. Mentally retarded people are not stigmatized for what they do, so they cannot undo it. They are stigmatized for what they are, and there is only one way to rectify that problem.

\section{REFERENCES}

Berman, I.

1967 "Mental Retardation and Depression," Mental Retardation, $5(6): 19-21$.

Bialer, I.

1970 "Emotional Disturbance and Mental Retardation: Etiologic and Conceptual Relationships," in F.J. Menolascino, (ed.), Psychiatric Approaches to Mental Retardation, New York: Buck, P.S. Basic Books, pp. 68-90.

1950 "The Child Who Never Grew," Ladies Home Journal, May, 134. Duff, C.J. and A. Campbell

1973 "Moral and Ethical Dilemmas in the Special-Care Nursery," New England Journal of Medicine, 289:890-894.

Dunn, L.M.

1961 "A Historical Review of the Treatment of the Retarded," in J.H. Rothstein, (ed.), Mental Retardation: Readings and $\mathrm{Re}$ Edgerton, R.B. ources, New York: Holt, Rinehart and Winston, pp. 13-17.

1967 The Cloak of Competence: Stigma in the Lives of the Mentally Retarded, Berkeley: University of California Press.

Farber, B.

1960 "Family Organization and Crisis: Maintenance of Integration in Families with a Severely Retarded Child." Monographs of Society for Research in Child Development, p. 25.
1968 Mental Retardation: Its Social Context and Social Consequences, Boston: Houghton Mifflin.

Frampton, M.E. and H.G. Rowell

1938 Education of the Handicapped, Volume I, History, Yonkers, New York: World Book Co.

Gearheart, B.R. and F.W. Litton

1975 The Trainable Retarded: A Foundations Approach, St. Louis: Goffman, E. C.V. Mosby.

1963 Stigma: Notes on the Management of Spoiled Identity, EngleGottwald, $\mathrm{H}$

1970 Public Awareness About Mental Retardation, Arlington, VirGreenfeld, J. ginia: The Council for Exceptional Children.

1978 A Place for Noah, New York: Holt, Rinehart and Winston.

Hardman, M. and C. Drew

1978 "Life Management Practices with the Profoundly Retarded: Issues of Euthanasia and Withholding Treatment," Mental Hart, N.W. Retardation, 16(6):390-396.

1970 "Frequently Expressed Feelings and Reactions of Parents Toward Their Retarded Children," in N.R. Bernstein (ed.), Kanner, L. Diminished People, Boston: Little, Brown, pp. 47-71.

1964 A History of the Care and Study of the Mentally Retarded, Springfield, Illinois: Charles C. Thomas.

Kelly, N.K. and F.J. Menolascino

1975 "Physicians' Awareness and Attitudes Toward the Retarded," Kurtz, R.A. Mental Retardation, 13(6):10-13.

1977 Social Aspects of Mental Retardation, Lexington, Mass.: LexingLove, H.D. ton Books.

1973 The Mentally Retarded Child and His Family. Springfield, Luther, $\mathrm{M}$. Illinois: Charles C. Thomas.

1652 Colloquia Mensalia, London: W. Du-Guard.

McCormick, R.A.

1974 "To Save or Let Die," Journal of the American Medical Association, 229(2):172-176.

Michaels, J. and H. Schucman

1962 "Observations on the Psychodynamics of Parents of Retarded Children," American Journal of Mental Deficiency, 66:568-573. 
The National Association for Retarded Citizens

1974 Avenues to Change: Book III: Effective Advocacy, Arlington, Texas: The Association.

Olshansky, $\mathrm{S}$

1966 "Parent Responses to a Mentally Defective Child," Mental Retardation, $4: 21-23$

The President's Committee on Mental Retardation

1973 Silent Minority, Washington, D.C.: U.S. Government Printing Office.

Richard, B.W.

1976 "Health and Longevity," Mental Retardation and Developmental Disabilities, 8:168-187.

Robertson, J.A.

1975 "Involuntary Euthanasia of Defective Newborns," Stanford Law Review, 27(2):215; 269.

Snyder, R.

1966 "Personality Adjustments, Self-Attitudes, and Anxiety Differences in Retarded Adolescents," American Journal of Mental Deficiency, 71:33-41.

Solnit, A.J. and M.H. Stark

1961 "Mourning and the Birth of a Defective Child," in The Psychoanalytic Study of the Child, 16:523-548.

Tringo, J.L.

1970 "The Hierarchy of Preference Toward Disability Groups," Waskowitz, C Journal of Special Education, 4:295-306

1959 "The Parents of Retarded Children Speak for Themselves," Journal of Pediatrics, 54:319-329.

Watts, A.

1951 The Wisdom of Insecurity, New York: Random House.

White, W.D. and W. Wolfensberger

1969 "The Evolution of Dehumanization in Our Institutions," Mental Retardation, 7:5-9.

Wolfensberger, W.

1972 Normalization, Toronto: National Institute on Mental Retardation.

1981 "The Extermination of Handicapped People in World War Iî German," Mental Retardation, 19(1):1-7.

Zaharia, E.S. and A.A. Baumeister

1978 "Technician Turnover and Absenteeism in Public Residential Facilities," American Journal of Mental Deficiency, 82:580593.

Zigler, E.

1970 "Familial Mental Retardation: A Continuing Dilemma," Science 155:292-298, cited in N. Bernstein, Intellectual Defici and Personality Development, in N. Bernstein, (ed.), Diminished People, Boston: Little, Brown, p. 178.

\section{THE “INTRODUCTORY SOCIOLOGY SURVEY”: \\ AN INSTRUMENT TO FACILITATE TEACHING EFFECTIVENESS}

\author{
Clarence Park \\ Texas AEM University
}

Chester Ballard

Longwood College

Elizabeth Maret

Texas A\&M University

Mid-American Review of Sociology, 1981, Vol. VI, No, 2:61-77

Many colleges and universities in recent years have shown an increased interest in the teaching effectiveness of their faculty. College-wide teacher rating instruments have become commonplace in many classrooms, including the introductory sociology classroom. Sociologists often express concern over these collegewide instruments for at least two reasons. First, sociologists have been rated generally by students as poor teachers (Linsky and Straus, 1973). Second, the applicability of these broad instruments to varied courses and circumstances is often questionable (Goldsmid and Wilson, 1980).

Many sociologists do not believe current instruments to be good measures of the effectiveness of sociology instruction. Nevertheless, demands for accountability exist, and may indeed increase as college budgets tighten and enrollments drop. Given both administrative demands and professional needs for assessment, the "Teaching Effectiveness Group" in the Sociology Department at Texas A\&M University has developed an "Introductory Sociology Survey." This instrument is designed with two major objectives in mind:

1. to provide information for the use of individual instructors in planning course materials relevant to the experiences of students; and 